\title{
POPULATION AGEING IN JAPAN: POLICY LESSONS FOR SOUTH-EAST ASIA
}

\author{
David E. Horlacher ${ }^{*}$ and Landis MacKellar ${ }^{* *}$
}

The paper reviews population trends in Japan with a view to showing that there has been substantial ageing of the Japanese population since 1950. The next 50 years will intensify this trend. The paper also analyses the economic consequences of this process and draws conclusions and lessons for the South-East Asian economies that are facing a similar demographic trajectory.

When the Japanese children who are born this year are themselves elderly, they will be living in a nation that is continuing to grow smaller and older. Will such a nation be able to make the necessary savings and be able to increase the labour productivity to the degree that will be needed to support those children in their old age? ${ }^{1}$ And what will all this mean for other regions of the world, such as South-East Asia?

Projections of population decline and population ageing have caused the Japanese Government to fear a loss of economic dynamism and difficulties in financing its pension and health schemes. Businessmen worry about the loss of customers and labour shortages and middle-aged adults worry about the availability of support in old age (Ogawa 2000). This widespread concern in Japan about population ageing is a prudent response to a demographic inevitability. In future decades, its population will age more rapidly than any country has ever done before. The proportion of the aged population will double from 10 to 20 per cent in less than 25 years. In contrast, most European countries took more than 50 years to travel the same distance. It should be noted, however, that some countries in South-East Asia, such as Singapore and Thailand, are set to traverse this distance even more rapidly than Japan.

Population ageing is a normal part of the modernization process whereby increased opportunities for women lead to lower fertility and improved medical care extends the life spans of older adults. In Japan's case, however, the fertility of Japanese

\footnotetext{
* $\quad$ Middlebury College, Middlebury, VT, United States.

** Social Security Reform Unit, International Institute of Applied Systems Analysis, Laxenburg, Austria.

1 An extended discussion of these issues can be found in Horlacher (2001a) and Horlacher (2001b).
} 
women fell faster than had ever occurred before, even as Japan achieved one with the world's highest life expectancies at birth in just a few decades. Furthermore, there are few signs of self-correcting tendencies that would slow the population ageing process or even prevent its acceleration.

This paper will first review population trends in Japan with a view to showing that there has already been substantial ageing of the Japanese population and that the next 50 years should bring additional ageing. Furthermore, there is little likelihood that these trends can be reversed. The first section of this paper describes the economic issues raised by the ageing of the Japanese population in the context of population decline. Emphasis is placed on the role of population ageing in the accumulation of capital, labour and technological progress and in the fiscal problems facing the Japanese pension and health systems. The last section of this paper argues that the experiences of Japan are very relevant to the countries of South-East Asia. The future demographic trajectory of the region closely tracks the actual path of the Japanese population during the last half-century. Assuming that the future economic and demographic situation of South-East Asia will be comparable to that observed in the case of Japan, a number of lessons based on the Japanese experience are drawn.

\section{THE POPULATION OF JAPAN WILL CONTINUE TO GROW OLDER}

As has been widely described, the population in Japan is close to peaking and will soon begin a prolonged decline. In this section we will focus on the age structure of the population and the determinants of current trends. The median age of the Japanese population has increased from 22 years in 1950 to 41 years in 2000 and by mid-century, fully half the population of Japan will be over the age of 53 (see figure 1.1).

Figure 1.1. Median age, Japan, 1950-2050

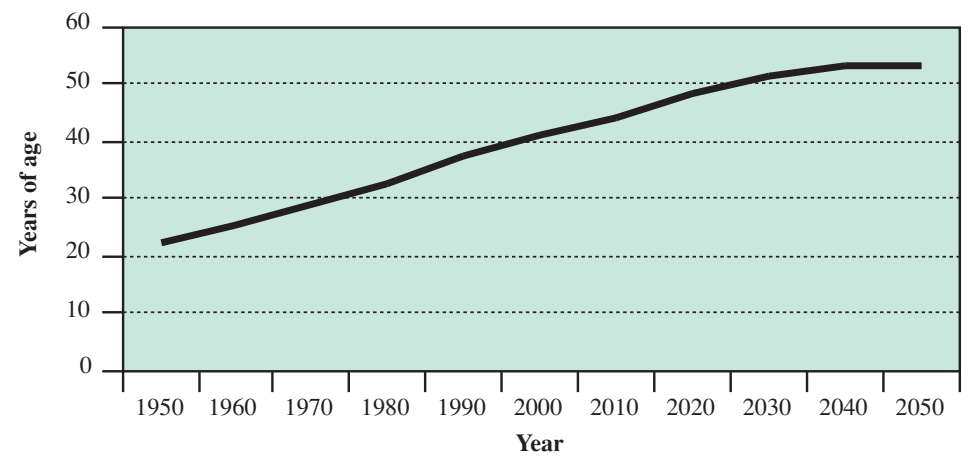

Source: United Nations, (2002) World Population Prospects Database. 
Declining fertility combined with increasing longevity will cause the Japanese population to age rapidly. The young-age share of the population, now 15 per cent of the total population, will fall to 11 per cent by 2050. The working-age population, now almost 70 per cent of the total will fall to 55 per cent in 2050. Meanwhile, the old-age (65+) share will grow from 17 per cent of the population today to more than 36 per cent in 2050 (see figure 1.2). No nation has ever experienced such rapid ageing.

Figure 1.2. Proportions of the population by age group, Japan, 1920-2050

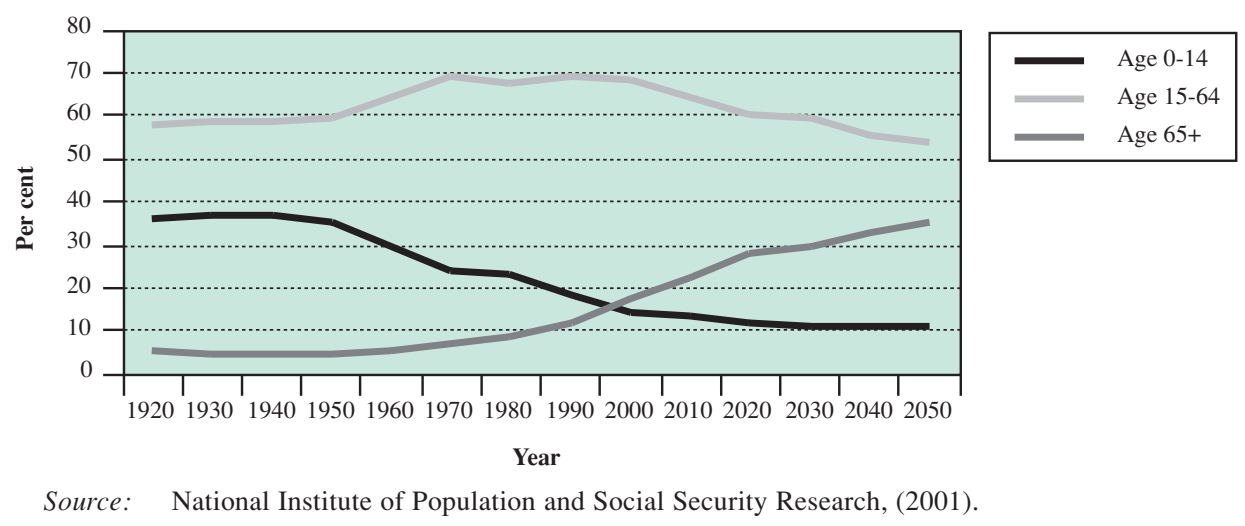

Figure 1.3 shows the population pyramids for Japan at three points in time, 1950, 2000 and 2050. Clearly the young cohorts that make up the base are shrinking while the elderly cohorts at the top are increasing. The young age groups declined and the older age groups increased. Projections for the first half of the twenty-first century indicate that this trend will continue. Not only will the young age groups (the groups that would give birth to the children) decline, so also will the working age groups. Only the dependent elderly will increase, thus placing a heavy burden on a shrinking working age population.

Figure 1.4 presents dependency rates. Between 1950 and 1970, Japan enjoyed a demographic "Golden Age" where the rapid decline in young age dependents caused the total dependency rate to fall. But by 2010 , the growing old-age dependency rate will start to push up the total dependency rate and by 2050, Japan will have more than 85 dependents for every 100 of working age.

The age structure was largely unchanged in the first half of the twentieth century because declines in infant mortality had offset the declines in fertility. By the end of the century, however, infant mortality had fallen to 3.3 infant deaths per thousand live births, leaving little scope for further improvement. In the second half of the 
Figure 1.3. Changes in the population pyramid
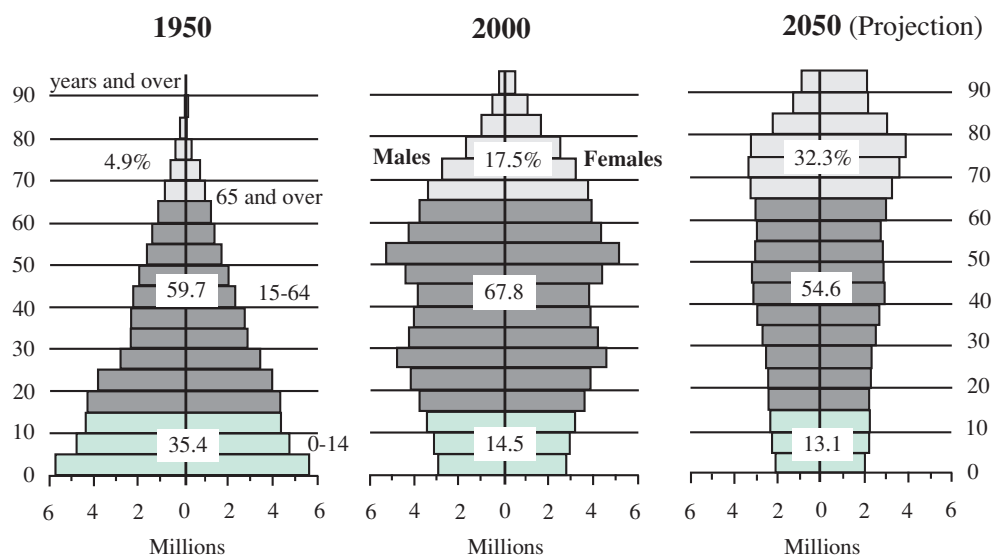

Source: $\quad$ Statistics Bureau, Ministry of Public Management, Home Affairs, Post and Telecommunications; Ministry of Health, Labour and Welfare.

Government of Japan, (2001).

Figure 1.4. Dependency rates, Japan, 1920-2050

(per cent of the working age population)

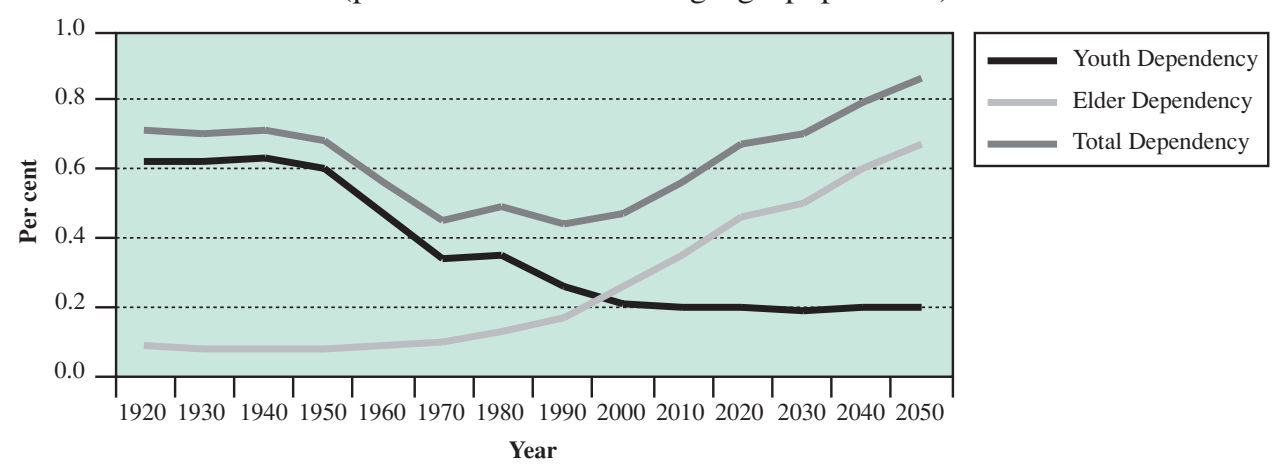

Source: National Institute of Population and Social Security Research, (2001).

twentieth century, lifestyle changes in Japan reduced deaths from heart disease and stroke, increasing life expectancy at age 65 and contributing to population ageing (see figure 1.5).

The main cause of the ageing of the Japanese population is the rapid decline in fertility, from a TFR of nearly 5 births per woman in 1930 to a TFR of 1.36 in 2000 (see figure 1.6). That is far below the replacement level. Though there has been a steady fall in the TFR, the marital total fertility rate has remained constant at 
Figure 1.5. Life expectancy at age 65 , males and females, Japan, 1950-2000

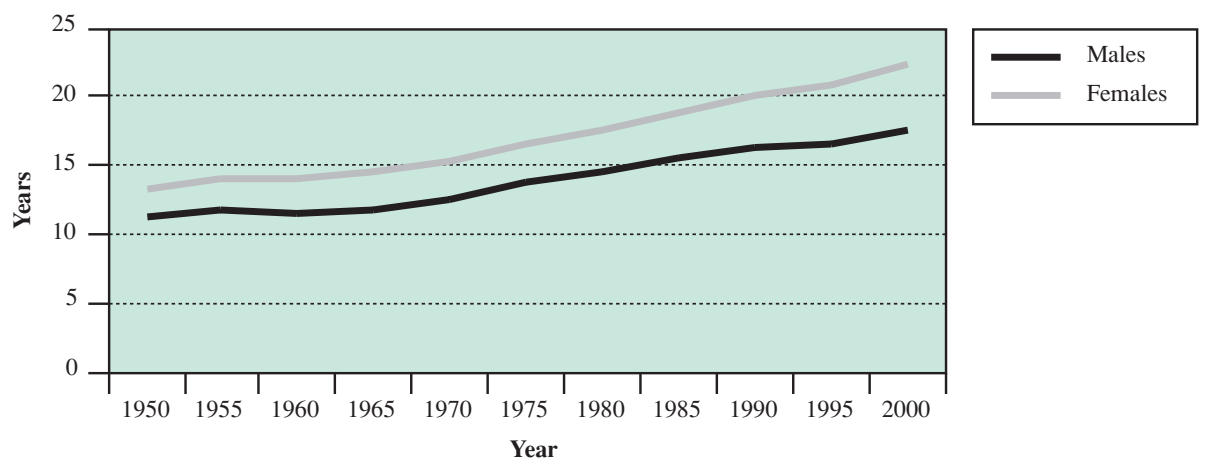

Source: National Institute of Population and Social Security Research, (2001).

Figure 1.6. Actual and replacement total fertility rates, Japan, 1930-2050

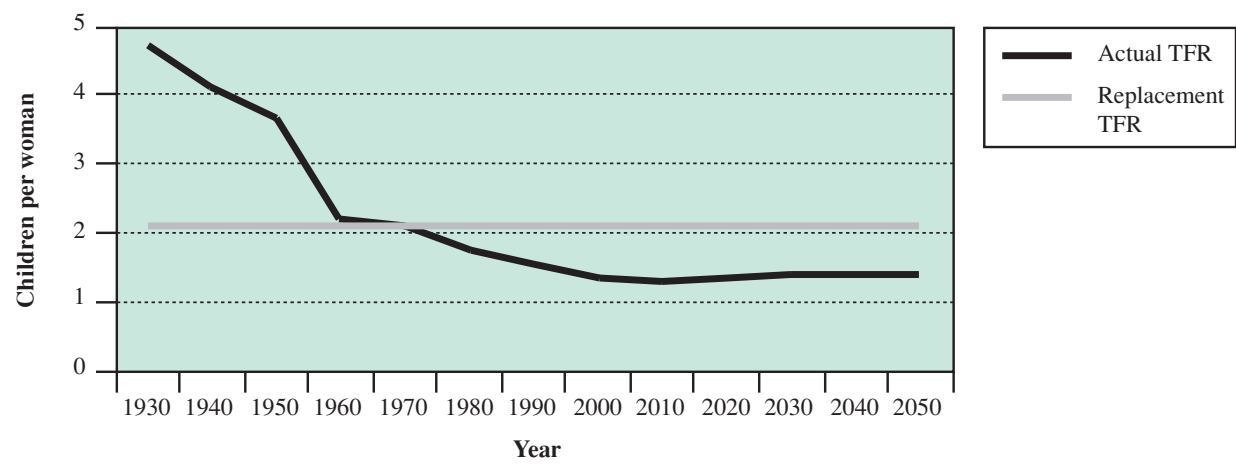

Source: National Institute of Population and Social Security Research, (2001) and (2002).

about 2.0 children per married woman because age-specific marital fertility rates have not changed (see figure 1.7).

The real causes of the fertility decline are delayed age at first marriage and increased lifetime celibacy. The proportion of Japanese women who are married has steadily declined because of higher ages at marriage and an increasing proportion of women who never marry at all. The average age at marriage has gone up by 3 years since 1975 and the proportion of women who are not likely to marry at all increased from 5 to 15 per cent in the same period. As a result, almost 50 per cent of Japanese women in the prime childbearing ages, 25 to 29 , are not married (see figure 1.8). 
Figure 1.7. Age-specific fertility rate for married women, Japan, 1950-2000

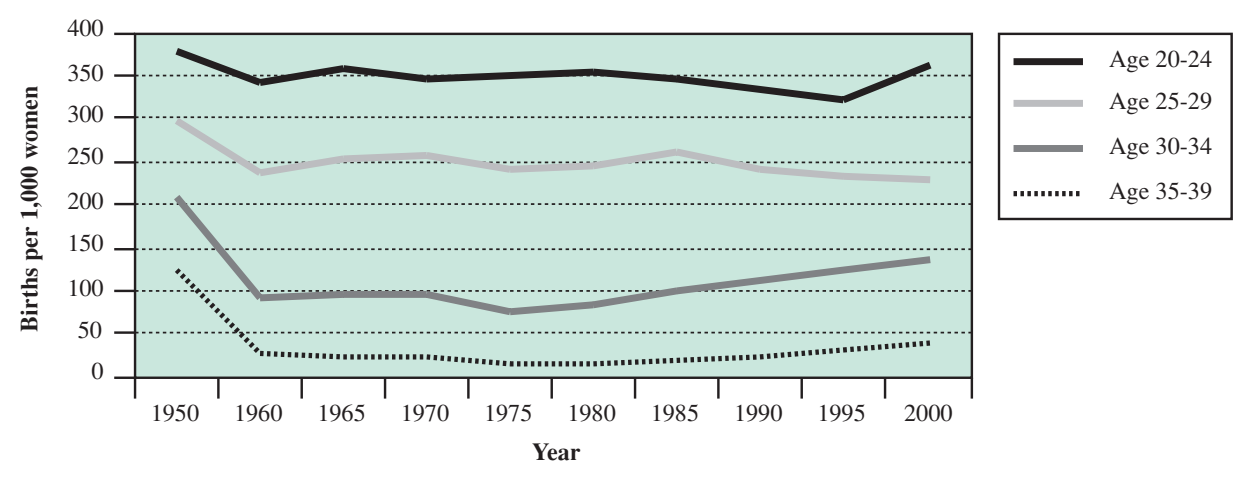

Source: National Institute of Population and Social Security Research, (2001).

Figure 1.8. Proportion of females never married, by age, Japan, 1930-2050

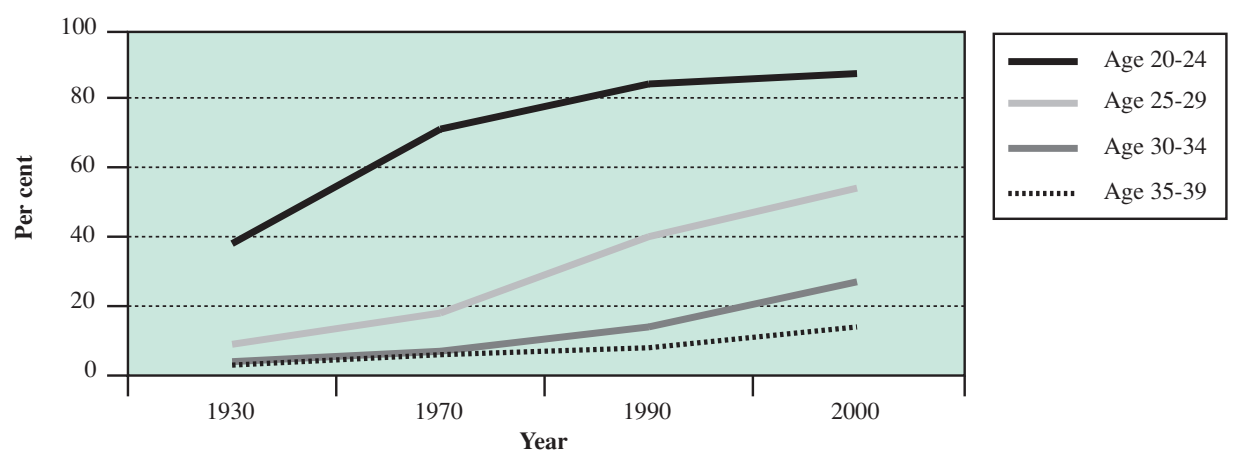

Source: National Institute of Population and Social Security Research, (2001).

Women are delaying marriage to take advantage of increased opportunities for higher education and improved employment opportunities. In Japan, the average age at marriage for women who are university graduates was about 28 years, as compared with about 26 years for high school graduates (see figure 1.9) As women have acquired more education, their salaries have increased, which in turn has raised the opportunity cost of withdrawing from the labour force to rear children. This is especially true for women under 30, whose wages rose from 70 per cent of men's wages in 1970 to almost 90 per cent in 2000. 
Figure 1.9. Enrolment rates in higher education, Japan, 1955-1995

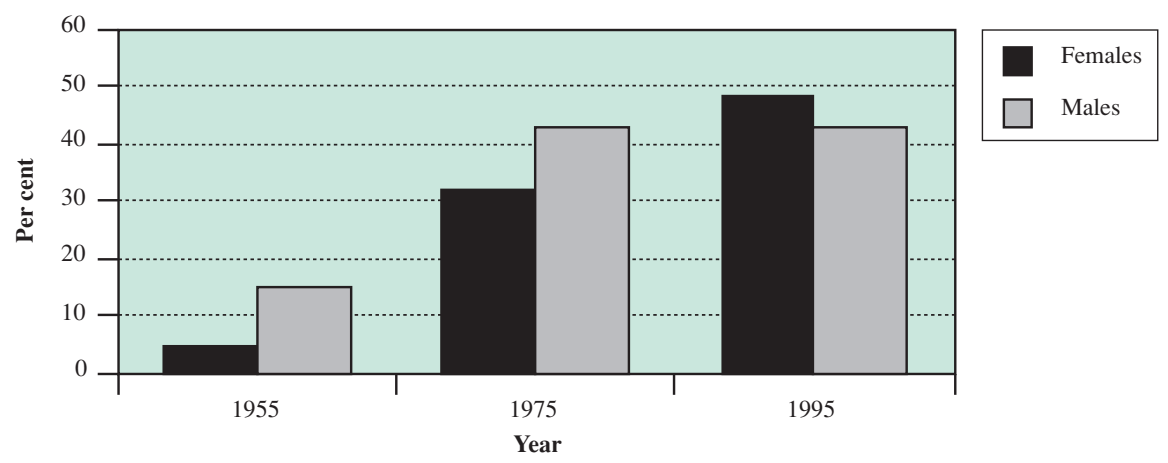

Source: Ogawa and Clark, (1995) and Mason and Ogawa (2001).

The pressure to care for the elderly contributes to lower fertility. By 2025, Japan will have 5.2 million elderly requiring full-time care. At the same time, there will be fewer middle-aged women to care for them. The likelihood that a woman may have to give up a full time job to care for an elderly parent is rapidly increasing. By 2025, almost half of non-working middle-aged women will be providing elder care.

The benefits of children are not what they once were in Japan. Already, fewer than half of elderly women live with their children. Furthermore, the steady improvement in public and private pension schemes has dramatically reduced the proportion of couples that plan to rely on their children for old-age support. While the value of children as a source of old-age support has been declining, the direct and opportunity costs associated with childrearing have been increasing. Though the Japanese Government provides monthly allowances for children, they do not cover the costs of having a child.

It would be possible to prevent the ageing of the Japanese population by allowing increased international migration. However, such migration is not currently permitted nor is it likely to be permitted in the future. The United Nations (2001) has calculated the amount of migration necessary to keep the ratio of the working-age population to the retired-age population at its 1995 level. It has calculated that Japan would have to admit an average of 10 million immigrants per year over the next 50 years. Though such an inflow would maintain the age structure, it would result in the growth of the total population to 818 million in 2050. Furthermore, 87 per cent of that population would be comprised of immigrants or their descendants. 
Both fertility and mortality are likely to decline, while there is little chance of increased immigration. Hence, population ageing is a near certainty. Let us now consider how Japan will cope with the economic effects of ageing.

\section{THE ECONOMIC CONSEQUENCES OF POPULATION AGEING}

\section{Japanese GDP is growing slowly}

In the three decades between 1965 and 1995, Japanese real GDP more than tripled and by 2000, real GDP (in 1995 prices) had risen to 518 trillion yen (\$ 4.5 trillion), (Government of Japan, 2001) The years between 1945 and the mid-1970s was the period of most rapid growth (about 8 per cent per year). Since then, there has been a significant fall in the rate of growth of GDP. Figure 2.1 shows that the growth rate of Japanese GDP has been very low (or negative) during most of the 1990s.

Figure 2.1. Annual rates of growth of GDP, Japan, 1905-2000

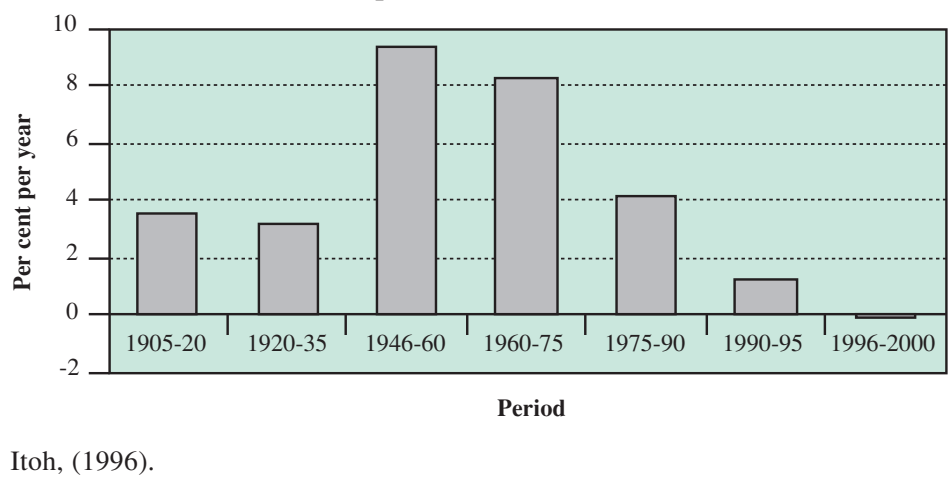

In 1960 , per capita GDP in Japan was equivalent to $\$ 4,700$ in purchasing power parity terms. By the year 2000, that figure had risen to $\$ 24,900$. The average annual rate of growth of per capita GDP had fallen 0.5 per cent between 1991 and 2000. The Japan Center for Economic Research (1998) projected that, over the next 25 years, total GDP will fall but per capita GDP will continue to grow, albeit slowly.

\section{Rates of saving and investment will decline}

The changing age structure will have three major impacts on Japan's productive capacity. It will reduce rates of saving and capital accumulation. It will shrink the labour force (though it may increase its stock of human capital). Finally, population ageing may slow the growth in total factor productivity. 
Currently Japan saves a little less than one-third of its GDP (see figure 2.2). The gross national saving rate peaked at about 1991 and has generally declined since then. Even so, Japan has the highest savings rate among the developed countries. It is considerably higher than the rates of Germany and the United States.

Figure 2.2. Gross national saving rate, Japan, 1984-1998

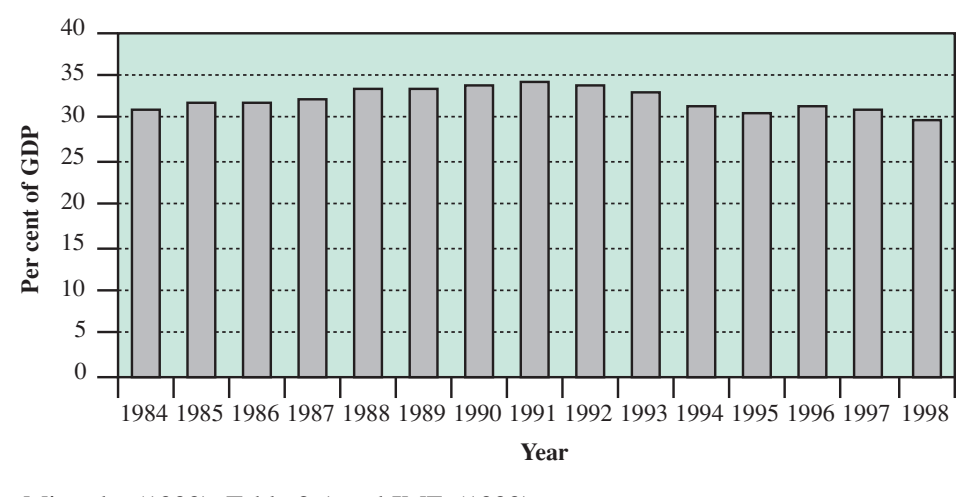

Source: $\quad$ Miranda, (1999), Table 2-1 and IMF, (1999).

The future course of Japanese savings rates will depend on the strength of the factors likely to reduce savings rates relative to factors likely to increase them. Among the former are: (1) the ageing of the population, (2) the decline in economic growth rates, and (3) an increase in the retirement age. Among the factors that are likely to increase savings rates in Japan are: (1) the decline in the labour force participation rates of the elderly, and (2) increases in life expectancy at retirement. It is likely the factors exerting downward pressure on saving will predominate. To forecast what will happen to savings rates, it is necessary to understand why they were so high in the past.

(i) Why were Japanese savings rates so high?

Many explanations revolve around the life cycle hypothesis of Modigliani and Brumberg (1980), which predicts that individuals will finance their consumption during retirement by dissaving. If the labour force is shrinking, then the saving of workers will fall short of the dissaving of retirees and there will be a negative effect on net household saving. If this hypothesis is true, the ageing of the Japanese population will put downward pressure on saving rates. 
Many of the challenges to the application of the life cycle hypothesis to Japan centre on whether the elderly really do dissave. Figure 2.3 presents a typical age profile of savings rates in Japan based on household survey data. It shows that even the oldest age group has a positive savings rate.

Figure 2.3. Saving rates by age group, Japan, 1999

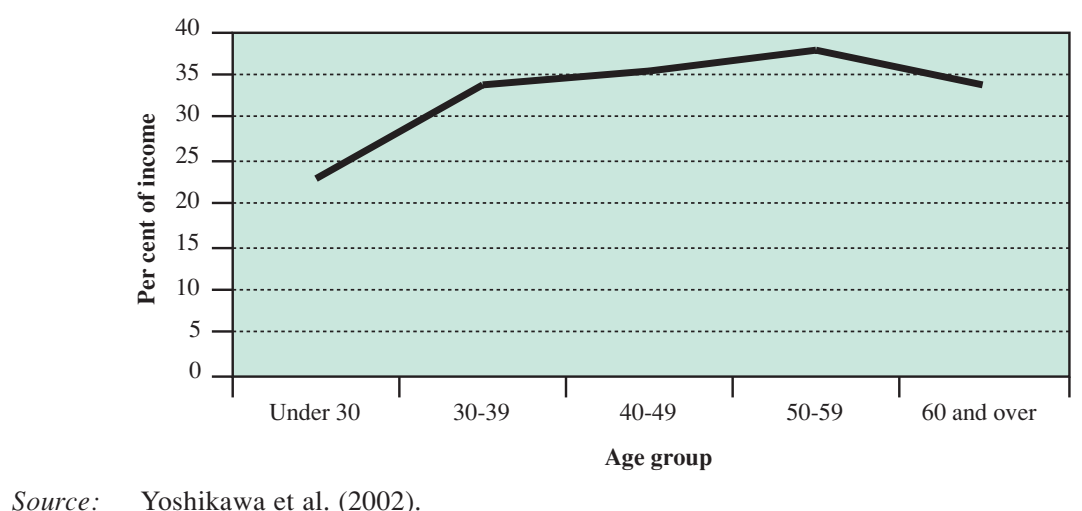

Yashiro (1997) contended that despite these age profiles, the elderly as a group, do indeed dissave. Often household-based studies look only at the one third of the elderly who maintain independent households, i.e. the households most likely to save. But about two thirds of the elderly population are dependent on their children and are often left out of household studies of elderly savings behaviour. When this factor is taken into account, his data show that the elderly do dissave as predicted by the life cycle theory.

The high labour force participation among Japanese males aged 65 and over might help to explain the high rate of savings in Japan. If so, efforts to increase the mandatory retirement age to 65 might reduce the household savings rate by increasing the labour force participation of the elderly. The life cycle hypothesis also predicts that the saving rate will increase along with life expectancy at retirement. Since the life expectancy of the Japanese population at older ages is increasing, this would also put upward pressure on the saving rate.

A number of hypotheses link Japan's high saving rate to its rapid rate of economic growth. One of these, the permanent income hypothesis, asserts that increases in Japanese income were not expected and were therefore considered to be transitory. Most of such income is saved. However time series studies have not supported explanations of Japan's high saving rates based on rapid income growth. For example, there was only a moderate decline in savings rates after 1974 even though there was a sharp decline in the growth rate of income. 
Researchers have made projections of future Japanese savings rates using a variety of techniques. Although there was no agreement on the amount of the decline, they all found that Japan's savings rate would decline in the twenty-first century. Horioka (1989), for example, projected that Japan's saving rate would become negative early in the twenty-first century and fall to levels between -10 and -20 per cent of personal income throughout the first half of the century (see figure 2.4).

Figure 2.4. Projected personal savings rates, Japan

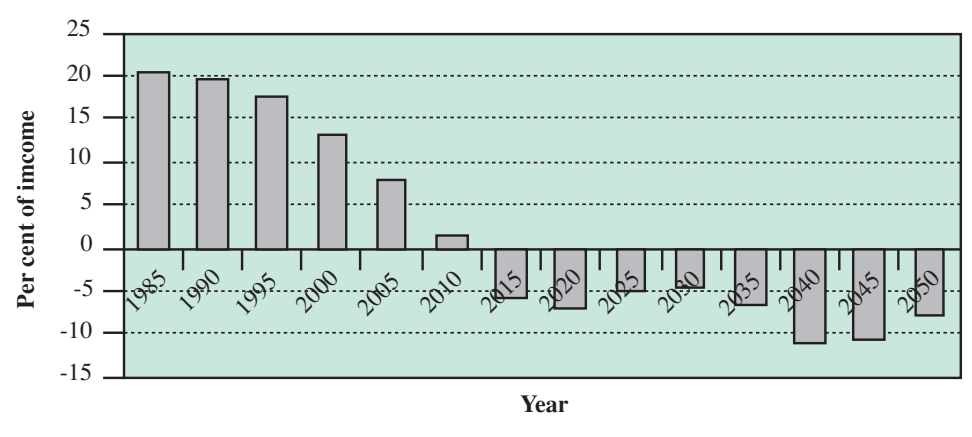

Source: Horioka, (1989).

Not all economists predicted an immediate decline in savings. Ando et al., (1995) projected that in the early stages of population ageing, the higher saving of middle-aged couples would more than offset the decline in saving by the oldest group of individuals and families. But after 2020, the share of children in the population will not decline very much while the share of persons 70 and above will rise significantly. Hence, the saving rate will drop to 10 per cent of income.

\section{Domestic and international investment}

The ultimate effect of population ageing on that balance will depend on the size of the decline in domestic investment relative to the decline in savings. If the decline in savings is greater, Japan's external balance will fall, since the current account balance relative to GDP is equal to the saving rate minus the domestic investment rate.

Population ageing will have opposing effects on domestic investment. On the one hand, a declining labour force may stimulate the demand for labour saving investment. On the other, the decline in profit rates due to the reduced labour supply and the higher interest rates may discourage investment. Auerbach et al. (1989), find 
that the decline in saving will ultimately outweigh the decline in investment and Japan's current account surplus will eventually become a current account deficit.

In a multi-country simulation analysis, Masson and Tryon (1990) found that over the period 1995-2025 the current account/GDP ratio would fall by 4 percentage points. In the process of declining by this much, the current account balance would be negative by 2000 and would continue to fall until at least 2015 .

Higgins and Williamson (1996) come to the opposite conclusion. They argued that an increasing old age dependency rate has a greater impact on domestic investment than on saving. Hence, the current account surplus of Japan is likely to grow. Williamson and Higgins (2001) predict that between 1990 and 2025, the share of the current account balance in Japan's GDP will increase by 2 percentage points. At this point, there seems to be no consensus on the effect that population ageing will have on Japan's future stock of foreign or domestic capital.

\section{The labour supply is shrinking}

Much of the economic growth of Japan occurred in the latter half of the 1950 s and 1960s when the labour force was growing rapidly and was therefore relatively young. At that time, employers could draw on a large stock of well-educated young workers who were willing to work for relatively low wages. The lower wages paid to young workers, combined with their high levels of education, powered Japan's economic growth. In the twenty-first century, however, the labour force will grow slowly and will continue to age (see figure 2.5 ).

Figure 2.5. Labour force growth rates, Japan, 1980-1990 to 2010-2020

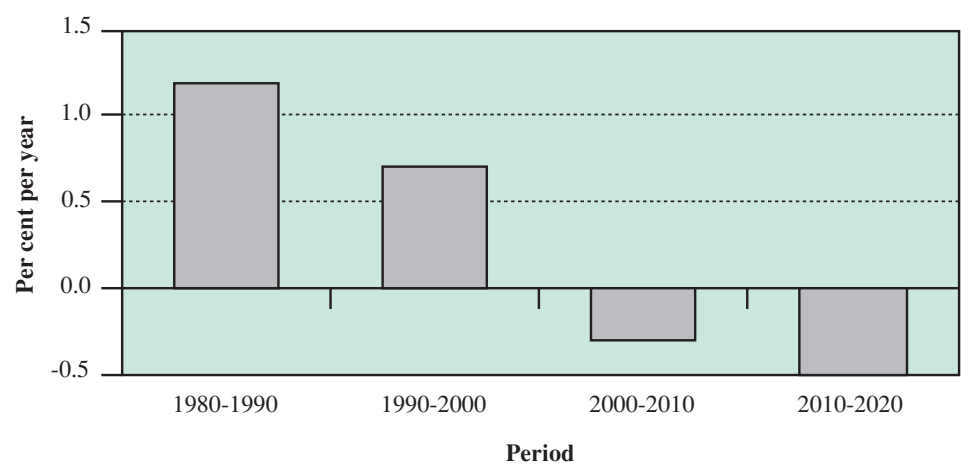

Source: $\quad$ Yashiro (1997), table 1. 
The Japanese labour force now embodies even more human capital. Between 1970 and 1988, the proportion of workers who had completed college or university had more than doubled. Chiefly as a result of economic development, but also as a result of changes in household composition, education and social welfare systems, there has been a significant decline in the labour force participation rates (LFPRs) of Japanese men and a much smaller decline in the LFPRs of women (see figure 2.6) There was a significant decline in the LFPRs of young people aged 15 to 19 , which was partially offset by a substantial increase in the LFPR of unmarried women aged 25-29.

Figure 2.6. Labour force participation rates, age 15 and above, Japan, 1960-2000

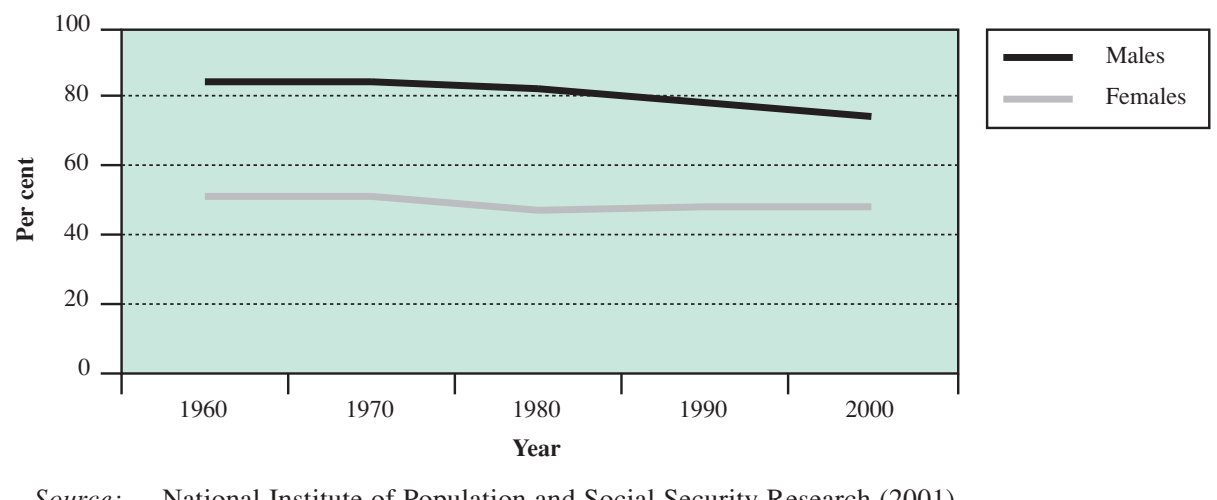

Source: National Institute of Population and Social Security Research (2001).

The LFPRs of the elderly males in Japan are quite high compared to other developed nations (see figure 2.7). Though these rates have been falling (see figure 2.8) Yashiro, et al. (1997) suggest that the labour force participation of older workers may increase as a result of the 2000 pension reforms, which reduced benefits and increased the age of eligibility for public pensions to 65 .

Historically, the distinguishing features of the Japanese labour market were a seniority-based wage system and lifetime employment. Those institutions provided workers with job stability and employers with high levels of effort and low turnover. Seniority-based wages, worked well when the labour force was growing rapidly. At that time, a large pool of younger workers who were receiving less than their productivity were supporting deferred payments to a smaller group of older workers who were receiving more than their productivity warranted. Since older workers were being paid more than their productivity, however, employers needed a system of mandatory retirement. 
Figure 2.7. Labour force participation rates of older males, selected OECD countries, 1996

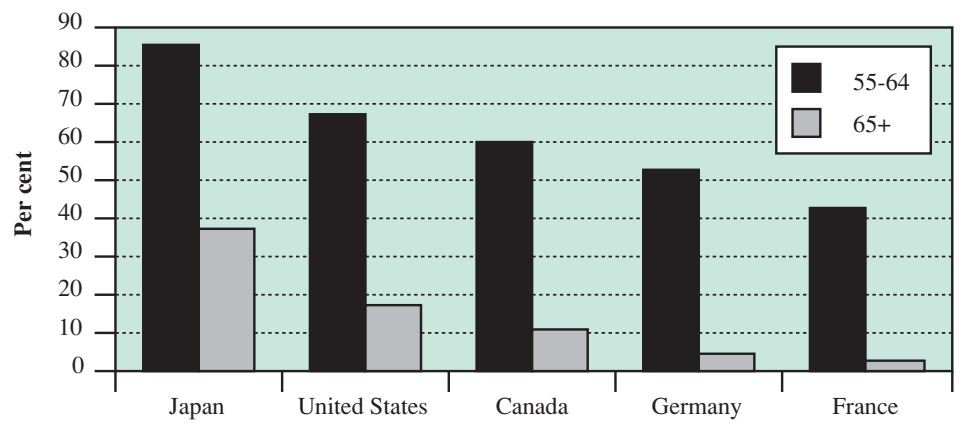

Source: $\quad$ OECD (1997) Labour Force Statistics.

Figure 2.8. Male labour force participation, aged 60-74, Japan, 1960-2000

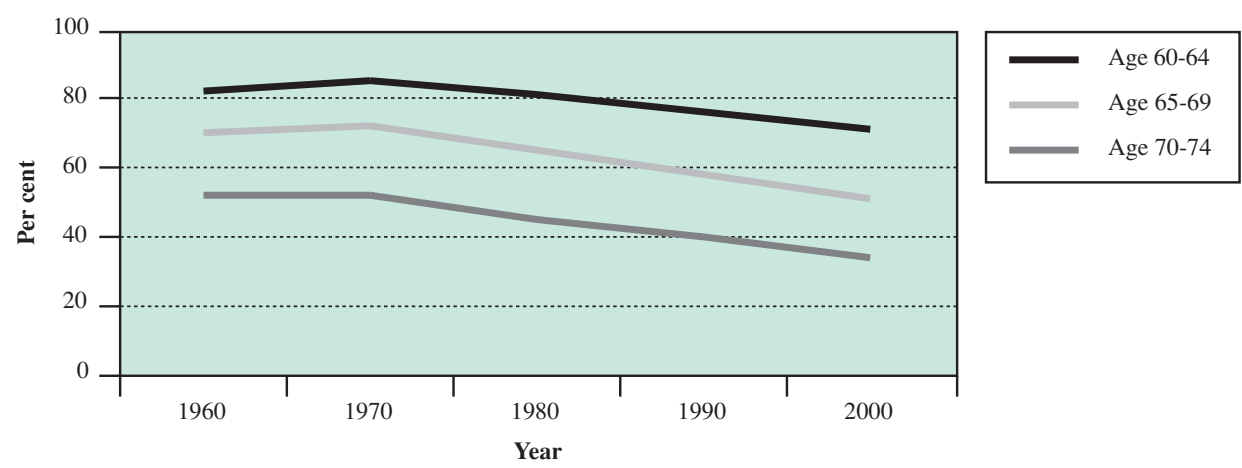

Source: National Institute of Population and Social Security Research (2001).

By the year 2000, more than 99 per cent of firms had set their mandatory retirement age at 60, or older (Ohtake and Yamaga, 2002). However, more than 70 per cent of them allowed some workers to continue past the mandatory retirement age or re-employed them at lower pay. On average, these men receive wages 20 to 40 per cent below their pre-retirement wages. It is this reduction in wages that has made it economical for employers to continue employing elderly workers.

The age of eligibility for public pensions is gradually increasing to age 65 . This will pose serious difficulties for those workers who were subject to mandatory retirement at age 60 and who are unable to find re-employment. Even now, elderly men suffer from 10 per cent rates of unemployment in Japan. 
Japan's labour supply is likely to fall rapidly in future decades. Not only is the working age population shrinking, hours worked per month and labour force participation rates are also declining. Furthermore, Japan can no longer assume that its labour force will be fully employed. Since the labour supply is likely to fall and the rate of capital formation is likely to stagnate, the chances of maintaining economic growth in the twenty-first century depend crucially on accelerating the rate of growth of productivity.

\section{Productivity growth is slowing}

Kosai, Saito and Yashiro (1998) demonstrated that increasing the efficiency of the economic system might largely offset the effects of population ageing and allow sustained economic growth in spite of a declining population. In the face of an increasing scarcity of labour, firms would seek to employ their workers more efficiently. Thus a decline in the labour supply should be accompanied by an increase in productivity.

Curiously, this does not seem to have happened in Japan where the slowing of labour force growth has been accompanied by a steady decline in the growth of various measures of productivity. From 1983 to 1990, Japanese total factor productivity grew at about 2.4 per cent per year. However that rate fell precipitously to 0.2 per cent per year in the following decade. Itoh (1996) had earlier shown that the rate of productivity growth has slowed (figure 2.9). Wolff (2001) found that the growth rate of labour productivity in manufacturing had fallen to less than one per cent per year in the early part of the 1990s. Japan's best real hope for avoiding economic stagnation is to increase productivity. However, Japan is already on the technological frontier. If productivity is to grow rapidly, Japan must take the lead in advancing industrial technology.

Figure 2.9. Growth rate of productivity, Japan, 1960-1992

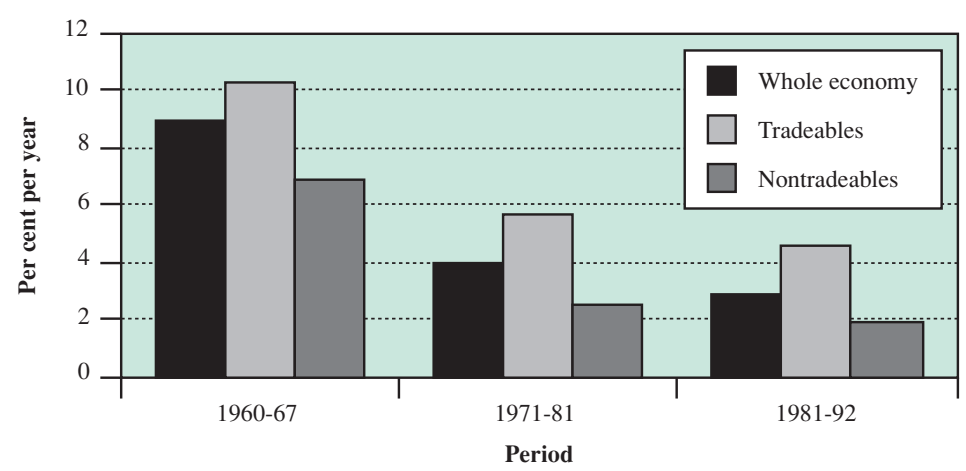

Source: Itoh (1996), table 3. 


\section{The fiscal impact of the pension and health systems}

Not only are the pension and health insurance schemes vitally important to the elderly population of Japan, they are also major determinants of whether the Government's accounts are in surplus or deficit and thus the national savings rate. In the future, the national saving rate may fall precipitously because of deficits in these schemes.

The Japanese social security system has three major components: medical care, pensions and welfare. Measured by expenditures, public pension schemes are the most significant components of the system. The economic impact of the social security system is enormous. In fiscal year 2002, social security contributions equaled 15.5 per cent of national income. Together, social security contributions and income taxes removed about 38 per cent of national income that might otherwise have gone to private consumption spending or saving.

\section{(i) Public pensions}

Japan's public pension system is essentially a pay as you go system in which current benefits are financed by current contributions. It is a two-tier system. The first tier, or National Pension Scheme (NPS), is a public programme that covers all residents older than 65 and provides them with a flat pension. The second tier, or Employee Pension Insurance (EPI), covers most salaried workers.

There was a major expansion of pension benefits in 1973. The replacement rate was increased to about 60 per cent. However, the newly expanded pension system quickly ran into trouble, and in 1986, revenues were increased and benefits reduced. By 1994, there had been a further deterioration of system finances and a new round of reform measures was introduced. The goal of the 1994 reform was to ensure that there would be adequate reserves even at the peak period of population ageing. However, the reforms were not sufficient to meet the demands placed on the pension system by Japan's rapidly ageing population. Yashiro and others (1997) warned that the large stock of assets in the pension system would be exhausted well before the peak in system dependency ratios. In the absence of further reforms, they projected huge deficits in the pension fund balances by 2050 (see figure 2.10).

Eventually it became clear that the 1994 pension reforms would not restore the Japanese Social Security programme to an actuarially sound basis. In March 2000 , the Diet enacted additional reforms that would cut lifetime pensions by about 20 per cent. Most importantly, pensions were to be indexed to consumer prices rather than wages. Thus, the real purchasing power of pensions would remain constant; even while the real incomes of contributors was rising.

The impact of this change can be gauged by comparing their projected replacement ratios, with and without pension reform. If pensions had continued to be 
Figure 2.10. Projection of pension fund balances, Japan, 1995-2050

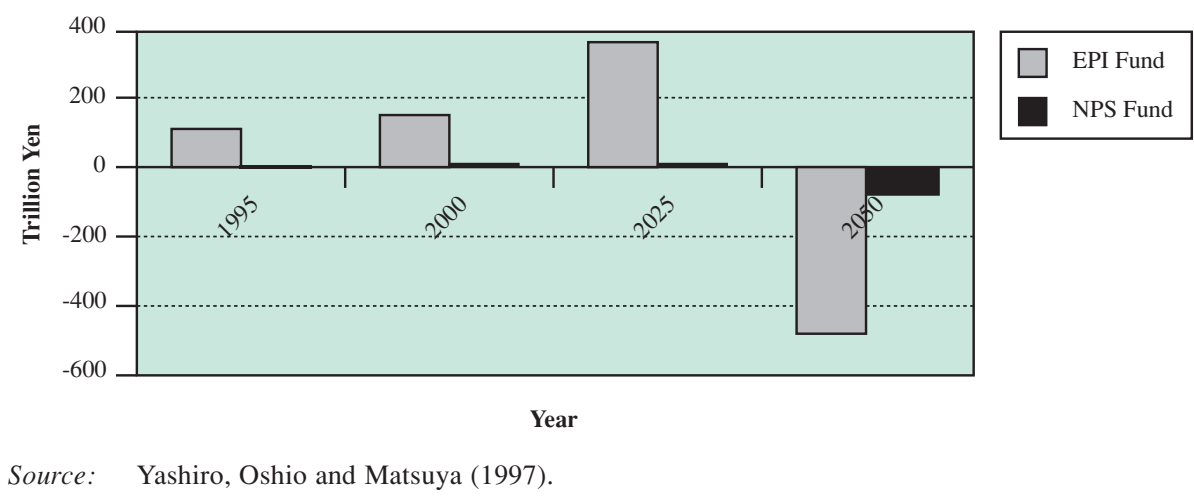

indexed to wages, the net replacement rate in 2050 would have exceeded 50 per cent of after tax income (Yashiro and others 1997). By indexing pensions to prices, the net replacement ratio will be cut to less than 20 per cent.

Since even the 2000 reforms may not be adequate to meet the pension obligations to a rapidly growing population of retirees, various options for reducing outflow and increasing revenues of the pension system are under consideration. One way to cut benefits is to link them to average life expectancy. Another option is to raise the age at which individuals become eligible for benefits from 65 years to 67 years.

The main drawback of these strategies is their adverse impact on the standard of living of the elderly. In 1999, pension payments accounted for roughly 60 per cent of the income of elderly households and about half of such households rely solely on public pensions for support. An additional problem is that an extension of the eligibility age for receiving a full pension may raise the already high unemployment rate of the elderly.

Many Japanese are concerned that the present system unfairly redistributes income from younger to older generations. The pension system also limits the labour force participation of older workers. When they reach age 60 , employees often have the option of continuing work at a considerably lower wage. If they do so, they may lose a part of their pension, because public pensions are subject to an earnings test.

\section{The health system}

Total medical care expenditures (both public and private) grew from about 6 per cent of national income in 1982 to about 8 per cent of GDP. Per capita medical 
expenditures grew at 5.5 per cent per annum between 1980 and 1997 and they are projected to grow by an additional 40 per cent over the next three decades.

The share of the elderly in total health care costs has risen from about 14 per cent in 1975 to 31 per cent in 1995; by 2025, the elderly are projected to account for half of total costs. In 1999, the annual medical costs of persons over 65 were 8.3 times the cost of those between 14 and 44 years old (see figure 2.11). Consequently the elderly who made up only 17 per cent of the population accounted for 51 per cent of aggregate medical expenses.

Figure 2.11. Annual cost of medical care by age group, Japan, 1999

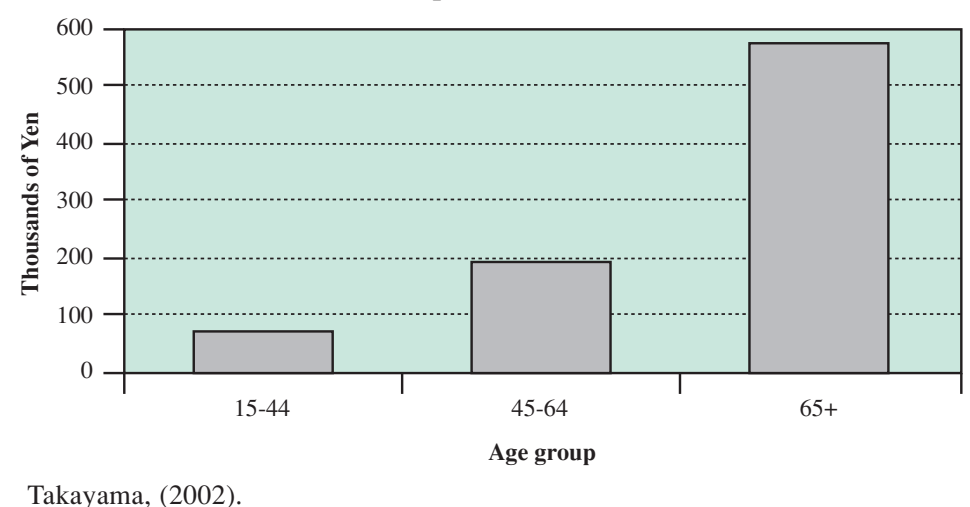

In 1990 the "Golden Plan" was instituted to reduce the demand for medical services by improving social services for the elderly and their families and by providing long-term care services. The major part of the Golden Plan is directed at improving home-based services for the elderly. In April of that year, Japan implemented a system of Long-Term Care Insurance. Because it covers care that was previously provided partly by health insurance and partly by welfare measures, the new programme will significantly decrease welfare spending. And by providing long-term care at home, it should reduce the demand for hospitalization and thereby slow the growth of medical spending.

In the absence of large-scale international migration to Japan, it is virtually certain that the dependency ratios of its various pension and health programmes will grow rapidly in the next half century. The only way to lighten the heavy burden that must be borne by the working age populations of the future will be to greatly increase their productivity. This will require a reversal of current trends in saving rates and productivity growth, a task made more difficult because those trends are also the effects of population ageing. 


\section{IMPLICATIONS OF THE JAPANESE EXPERIENCE FOR SOUTH-EAST ASIA}

MacKellar and others (2002) observed that a half century ago "Japan was a poor country with a dismally overcrowded agricultural sector and an under-capitalized industrial sector producing simple consumer goods." Fifty years later, Japan is among the richest countries in the world. But reduced young age dependency that promoted a high savings rate is rapidly leading to increased old age dependency, with the opposite effect. In the next century we shall see the "unwinding" of the demographic component of the Japanese economic miracle.

There is good reason to expect that in the first half of the twenty-first century, the nations of South-East Asia will follow a demographic trajectory that closely tracks that of Japan in the last half of the twenty-first century. For South-East Asia the next 50 years will be a period of decelerating population growth combined with rapid population ageing. By 2150, the demographic profile of South-East Asia should closely resemble that of Japan in 2000 and many of the same economic issues currently facing Japan will be challenging the nations of South-East Asia. However, the scale of these problems will be much larger in South-East Asia since its population in 2000 was more than 522 million as compared with a Japanese population of about 84 million in 1950 (United Nations 2002).

The 5.4 per cent growth rate of GDP in South-East Asia is not dissimilar to that of Japan in 1950. Nevertheless, South-East Asia must begin its economic climb from a much lower base. In the year 2000, per capita income in South-East Asia was $\$ 1,121$, about one fourth the per capita income in Japan in 1960 (\$ 4,672). Nevertheless, it should be possible to draw some lessons from the Japanese experience that have policy significance for South-East Asia.

\section{Similar long run demographic trajectories}

Between 2000-2005 and 2045-2050, the growth rate of South-East Asia's population is projected to fall from 1.4 per cent per annum to 0.4 per cent. Between 1950-1955 and 1995-2000, the growth rate of the Japanese population fell by about the same amount, though not as smoothly (see figure 3.1).

In the next 50 years, the pattern of population ageing in South-East Asia will be nearly the same as that of Japan in the latter half of the twentieth century. In South-East Asia, the median age will rise from 24 years in 2000 to 38 years in 2050. The median age in Japan rose from 22 years in 1950 to 41 years in 2000 (see figure 3.2). The growth of the elderly population in South-East Asia will closely parallel that of Japan during the last half of the twentieth century (see figure 3.3). In South-East Asia, the population aged 65-and-older will rise from 4.7 per cent in 2000 to 16 per cent in 2050. In Japan, the population aged 65 -and-older rose from 4.9 per cent in 1950 to 17 per cent in 2000 . 
Figure 3.1. Growth rate of population, Japan and South-East Asia, 1950-1955 to 2045-2050
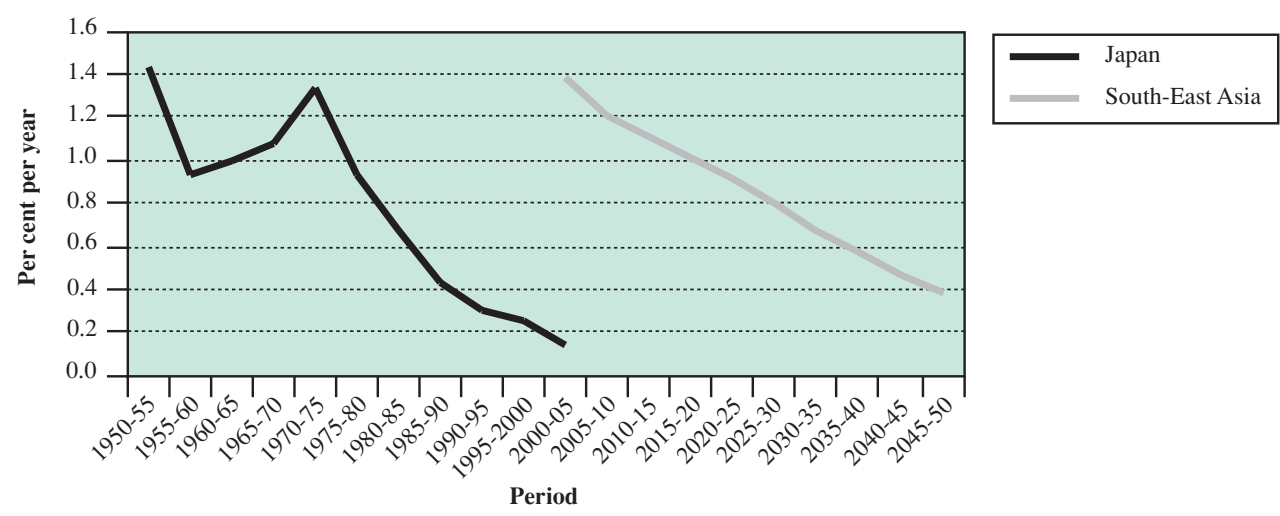

Source: United Nations (2002) Population Prospects Database.

Figure 3.2. Median age, Japan and South-East Asia, 1950-2050

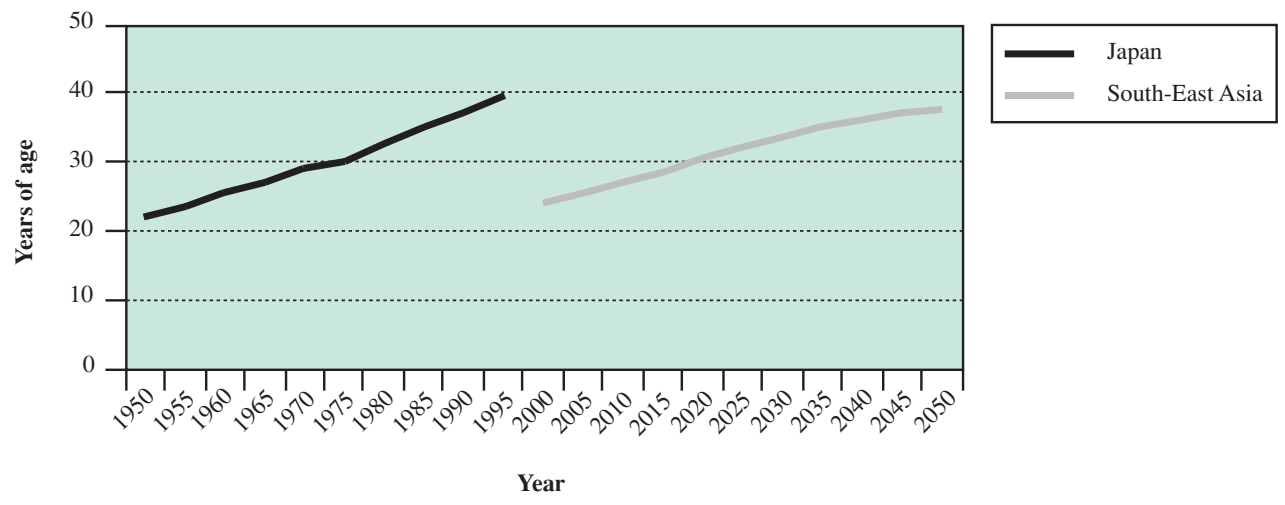

Source: United Nations (2002) Population Prospects Database.

Though the TFR is projected to fall rapidly in South-East Asia from 2.52 in 2000-2005 to 2.08 in 2045-2050, that is not nearly as rapid as the fall that occurred in Japan where the TFR collapsed from 2.75 in 1950-1955 to 1.36 in 2000 (see figure 3.4) However, the flattening of the TFR in South-East Asia is really an artifact of the United Nations' projection system. In reality, fertility in that region is likely to fall below replacement sometime before 2025 and continue falling.

As in the case of fertility, the decline in mortality in South-East Asia will not be quite as dramatic as in Japan during the last half of the twentieth century. 
Figure 3.3. Share of the population aged 65 and older, Japan and South-East Asia, 1950-2050

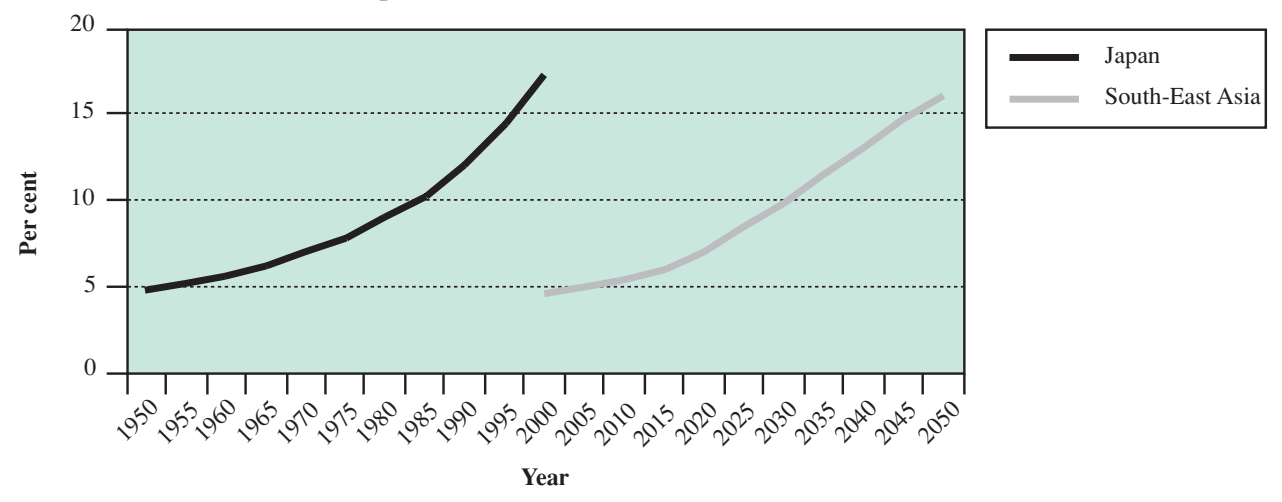

Source: United Nations (2002) Population Prospects Database.

Figure 3.4. Total fertility rate, Japan and South-East Asia, 1950-1955 to 2045-2050

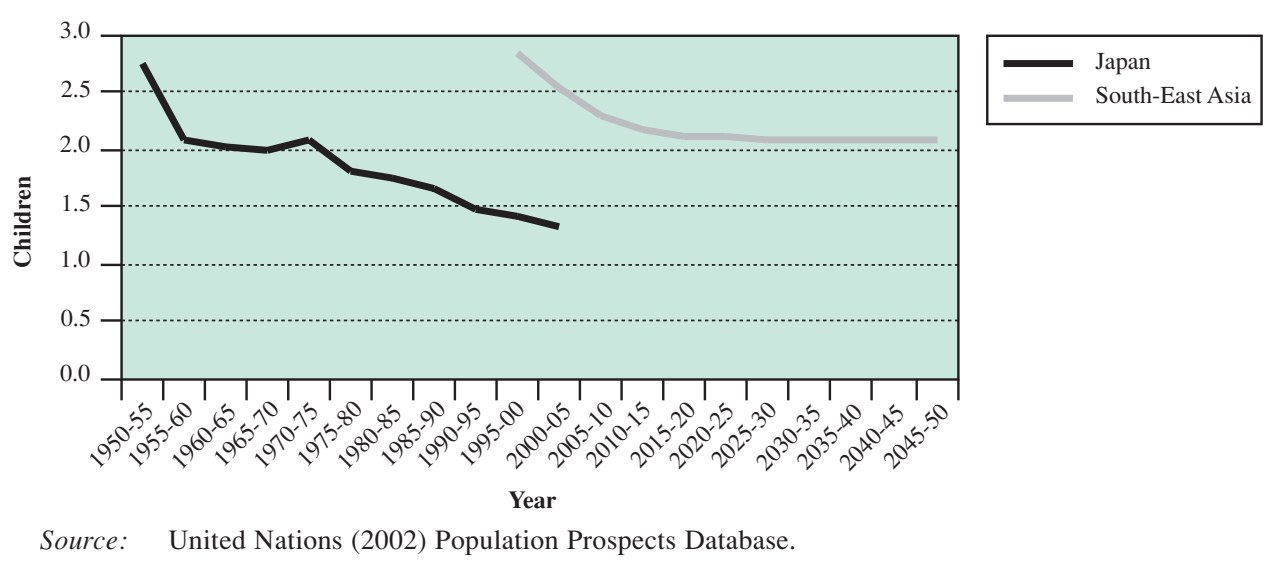

Life expectancy at birth for both sexes combined in South-East Asia was 67 years in 2000-2005 and is projected to rise to 77.3 years in 2045-2050, a gain of about 10 years. In Japan, combined life expectancy at birth grew from 64 years in 1950-1955 to 80.5 years in 1995-2000, a gain of 16.5 years (see figure 3.5).

Clearly, in the next half century, the demography of South-East Asia will tread the same paths as Japan traveled during the last half of the twentieth century. While some nations may travel that path a bit more slowly than Japan did, others may experience even more rapid ageing than Japan. Two such nations are Thailand and Singapore. 
Figure 3.5. Life expectancy at birth, Japan and South-East Asia, 1950-1955 to 2045-2050

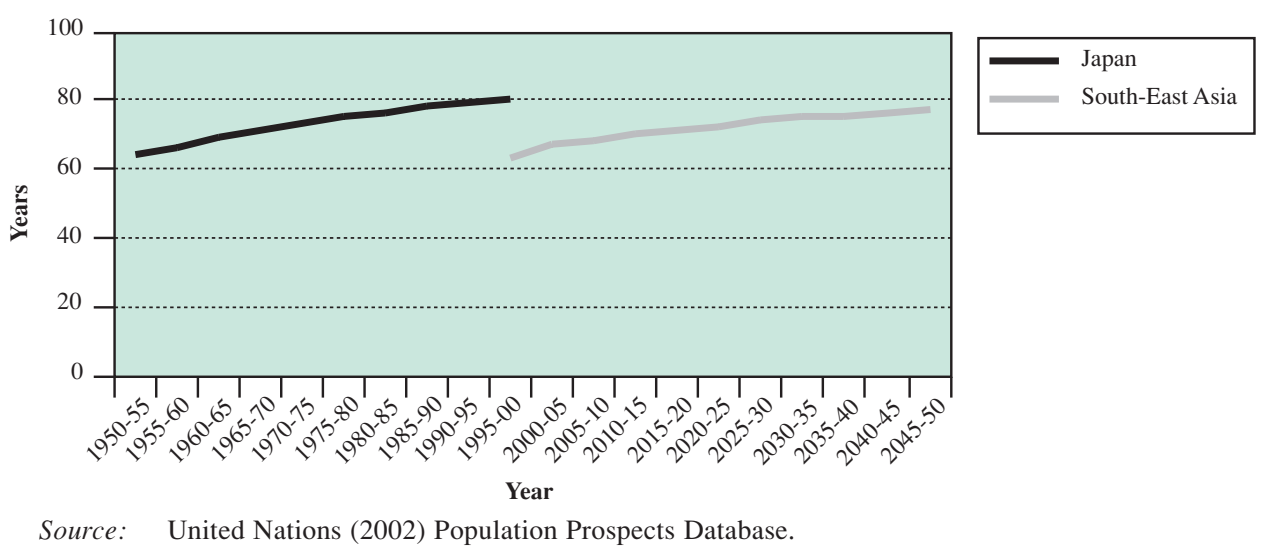

\section{Policy implications for South-East Asia}

Japan is on the frontier of our knowledge of how to adapt to a rapidly ageing population. She had to break the path that the nations of South-East Asia must follow. It should be possible to distill some insights from Japan's experience that might be applied by the nations of South-East Asia as they age rapidly over the next 50 years. Seven lessons that seem particularly useful are:

- $\quad$ Avoid increasing inequality

- $\quad$ Make more efficient use of the labour force

- $\quad$ Provide incentives for saving

- Be wary of investing abroad

- $\quad$ Promote the education of young people

- Limit commitments for public pensions and health care

- Index pensions to prices - not wages

We discuss each of these recommendations in turn.

Population ageing redistributes income from older workers to younger ones. It also increases the weight of age groups where the distribution of income is relatively equal to age groups in which it is not. In view of the already substantial degree of economic inequality in some South-East Asian nations, it will be necessary to undertake efforts in other spheres to offset the increasing inequality due to population ageing.

Making more efficient use of labour has three components: (1) maintain a flexible labour system; (2) employ scarce labour in the most efficient industries and (3) enable women in the prime childbearing ages to combine motherhood and careers. 
The Japanese labour market is characterized by lifetime employment, seniority-based compensation, and mandatory retirement at an early age. The economies of South-East Asia should try to avoid introducing such institutions into their labour markets since the Japanese experience proves that once in place, they are extremely difficult to remove, even in the face of a rapidly ageing labour force.

The countries of South-East Asia could offset the decline in their work forces by utilizing labour more efficiently. In particular, it should resist pressures to protect inefficient industries. By allowing markets to reallocate workers to their most productive occupations, the countries of South-East Asia can moderate some of the worst effects of a shrinking labour force. Conversely, they can economize on what will become scarce labour resources by specializing according to comparative advantage and opening their markets to imported goods.

Though there is some scope for increasing the labour input of elderly males, the increased utilization of women is Japan's best hope for preventing a precipitous fall in its labour force. However, in Japan, many factors, especially the lack of day care facilities for children and the lack of help with home-care of the aged, inhibit the labour force participation of women. As the societies of South-East Asia start to cope with labour force decline, they should do their utmost to eliminate the disincentives to female labour force participation. By doing so they could neutralize a very large part of the expected negative impact of demographic trends on their economies.

The ageing of the Japanese population is a significant factor underlying the decline in household savings. Hence, it is likely that population ageing will also put downward pressure on household savings rates in South-East Asia. It will also put pressure on government fiscal balances, especially the balances of the pension and health systems. Heller (1998) projects that for a time, saving rates will increase in the rapidly growing nations of South-East Asia. After 2025, however, the aggregate savings rate will decline. Therefore, the Governments of the region should offset a potential decline in their aggregate saving rates by providing significant incentives to savers.

In the past, Japan dealt with low domestic interest rates by investing in relatively capital-poor countries, such as the nations of South-East Asia. In future decades, it is likely that the countries of South-East Asia will also be investing abroad. However, they should be forewarned that empirical and analytical studies by MacKellar and Reisen (1998) and MacKellar and others (2002) indicate that the net returns to those investments are likely to be modest. On the other hand, investing domestically will yield higher wages and higher wage tax revenues.

The increasing real wage due to population ageing might induce younger cohorts to invest in more human capital, resulting in enhanced productivity. On the other hand, young cohorts might pass up advanced education to take advantage of higher wages. Hence, the countries of South-East Asia cannot assume that a slowing in the accumulation of physical capital will be offset by an increased rate of 
accumulation of human capital. They will have to actively promote the education of young people.

Before the 2000 pension reforms, an increase in real wages in Japan always caused an upward adjustment of pension benefits. As a result, the payroll contribution rate moved upwards in lockstep with increases in productivity. Increases in labour productivity failed to lighten the burden of the pension system because pensions rose proportionately through the indexation process. In establishing their pension systems, the nations of South-East Asia should link benefit levels to prices. If they do, wage-based contribution rates need not increase so long as productivity grows more rapidly than programme dependency rates.

Trends in fertility and mortality combined with an age structure that call for fewer women to enter the childbearing years and for more adults to enter old age, guarantees that over the next 50 years rapid population ageing in South-East Asia is inevitable. In the case of Japan, this process is leading to "economic stagnation". South-East Asia can avoid the same fate; but only if it acts wisely and soon. 


\section{REFERENCES}

Ando, Albert, A. Morro, J.P. Cordoba and G. Garland, 1995. "Dynamics of demographic development and its impact on personal saving: case of Japan" Richerche Economiche, September.

Auerbach, Alan J.; Laurence J. Kotlikoff, Robert Hagemann and Nicoletti Guiseppe, 1989. The Dynamics of an Ageing Population: The Case of Four OECD Countries. National Bureau of Economic Research Working Paper No. 2797, February.

Government of Japan, 2001. Statistical Handbook of Japan, Ministry of Public Management, Home Affairs, Posts and Telecommunications, Tokyo.

Heller, Peter, 1998. "Ageing in the Asian tiger economies", in Finance and Development, vol. 35, No. 2, June.

Higgins, Matthew and Jeffrey G. Williamson, 1996. Asian Demography and Foreign Capital Dependence, NBER Working Paper 5560, Cambridge, Massachusetts, National Bureau of Economic Research.

Horioka, Charles Y., 1989. "Why is Japan's private savings rate so high?” in Ryuzo Sato and Takashi Negishi, eds., Developments in Japanese Economics (Tokyo, Academic Press), Harcourt Brace Jovanovich Japan Inc., pp. 145-178.

Horlacher, David, 2001a. Ageing in Japan: Causes and Consequences, Part I: Demographic Issues, International Institute of Applied Systems Analysis, Laxenburg, Austria, Interim Report IR-01-008, February.

, 2001b. Ageing in Japan: Causes and Consequences, Part II: Economic Issues, International Institute of Applied Systems Analysis, Laxenburg, Austria, Interim Report IR-01-009, February.

International Monetary Fund,1999. Japan: Economic and Policy Developments, IMF Country Report 99/114, October, Washington, D.C.

Itoh, Takatoshi, 1996. "Japan and the Asian economies: a miracle in transition" Brookings Papers on Economic Activity, vol. 2, pp. 205-272.

Japan Center for Economic Research, 1998. “Japan's balance sheet in 2025 - long term economic projections", http://www.jcer.or.jp/eco/97long.html

Kosai, Jun Saito and Naohiro Yashiro, 1998. Declining Population and Sustained Economic Growth: Can They Co-Exist? JCER Discussion Paper No. 45.

MacKellar, Landis; Tania Ermolieva; David Horlacher and Leslie Mayhew, 2002. Economic Impacts of Population Ageing in Japan, Interim Report for the Fourth International Forum of the Collaboration Projects, Economic and Social Research Institute, Cabinet Office, Government of Japan.

MacKellar, L., and H. Reisen, 1998. A Simulation Model of Global Pension Investment. Ageing Working Papers AWP 5.5. Paris, OECD.

Mason, Andrew and Naohiro Ogawa, 2001. “Population, labour force, saving and Japan's future” in Japan's New Economy, edited by Magnus Blomstrum, Byron Gagnes and Sumner La Croix, Oxford University Press, Oxford, pp. 48-74.

Masson, Paul R. and Ralph W. Tryon, 1990. "Macroeconomic effects of projected population ageing in industrial countries", International Monetary Fund Staff Papers, vol. 37, No. 3, pp. 453-485, September.

Miranda, Kenneth,1999. "Does Japan save too much", in Saving Behaviour and the Asset Price "Bubble" in Japan, IMF Occasional Paper No. 124, pp. 4-15. 
Modigliani, Franco, 1980. The Collected Papers of Franco Modigliani, vol. 2, The Life Cycle Hypothesis of Saving, Andrew Abel, ed., Cambridge, Massachusetts, MIT Press.

National Institute of Population and Social Security Research, 2001. "Selected demographic indicators for Japan," http://www.ipss.go.jp/English/S_D_I/Indip.html , 2002. "Population projections for Japan, 2001-2050", mimeo, January.

Ogawa, Naohiro, 2000. "Policy options for meeting the challenge of an ageing society: the case of Japan”, Ageing in Japan 2000, Japan Ageing Research Center, pp. 75-104.

Ogawa, Naohiro, and Robert L. Clark, 1995. "Earnings patterns of Japanese women: 1976-1988", Economic Development and Cultural Change, vol. 43, No. 2, pp. 293-313.

Ohtake, Fumio and Hisaki Yamaga, 2002. "The effects of the old age pension system for active employees on the labour supply of elderly male workers", in The Economic Effect of Fewer Children and Ageing and Desirable Policy Reform, Part II, Interim Report for the Fourth International Forum of the Collabouration Projects, Economic and Social Research Institute, Cabinet Office, Government of Japan, pp. 235-255.

Organization of Economic Cooperation and Development, 1997. Labour Force Statistics, 1976-1996 OECD, Paris, pp. 532-586.

Takayama, Noriyuki, 2002. "Never-ending Reforms of Social Security in Japan”, mimeo.

United Nations, 2001b. Replacement Migration: Is it a solution to declining and ageing populations, Department of Economic and Social Affairs, Population Division, ST/ESA/SER.A/206.

, 2002. United Nations, Population Division, World Population Prospects, Population Database, http://esa.un.org/unpp/.

Williamson, Jeffrey G. and Matthew Higgins, 2001. "The accumulation and demography connection in East Asia" in East Asia: Challenges Met, Opportunities Seized, Andrew Mason, ed., Stanford University Press, Stanford, CA, pp. 123-154.

Wolff, Edward N., 2001. "Has Japan specialized in the wrong industries?” in Japan's New Economy, edited by Magnus Blomstrum, Byron Gagnes and Sumner La Croix, Oxford, Oxford University Press, pp. 175-197.

Yashiro, Naohiro, 1997. "Ageing of the population in Japan and its implications to the other Asian countries", Journal of Asian Economics, vol. 8, No. 2, Summer. Greenwich, Connecticut, pp. 245-261.

Yashiro, Naohiro, Takashi Oshio and Mantaro Matsuya, 1997. Macroeconomic and Fiscal Impacts of Japan's Ageing Population with Specific Reference to Pension Reforms, Discussion Paper No. 78, Economic Research Institute, Economic Planning Agency, Tokyo, Japan, September.

Yoshikawa, Hiroshi, Kiyohiko Nishimura, Masato Shirai and Shinichi Fukuda, 2002. Ageing and Economic Growth, Interim Report for the Fourth International Forum of the Collaboration Projects, Economic and Social Research Institute, Cabinet Office, Government of Japan, pp. 1-10. 